\title{
Pengaruh Opini Going Concern, Financial Distress, dan Kepemilikan Institusional Pada Auditor Switching
}

\author{
Gusti Agung Ayu Intan Permata Sari ${ }^{1}$ \\ Ida Bagus Putra Astika ${ }^{2}$
}

\author{
${ }^{1}$ Fakultas Ekonomi dan Bisnis Universitas Udayana (Unud), Bali, Indonesia \\ email: iinpermatag@gmail.com / Tlp: 081239357088 \\ ${ }^{2}$ Fakultas Ekonomi dan Bisnis Universitas Udayana (Unud), Bali, Indonesia
}

\begin{abstract}
ABSTRAK
Auditor switching merupakan pergantian auditor maupun Kantor Akuntan Publik (KAP) yang dilakukan oleh perusahaan klien. Pergatian auditor (auditor switching) yang dilakukan oleh perusahaan klien merupakan salah satu solusi potensial yang dapat diambil untuk mengatasi kemungkinan munculnya permasalahan penurunan kualitas audit yang disebabkan oleh masa auditor yang panjang. Permasalahan penurunan kualitas audit tersebut, banyak disebabkan oleh berkurangnya independensi dan objektivitas auditor maupun Kantor Akuntan Publik (KAP) terhadap perusahaan klien akibat adanya hubungan yang lama terjalin antara auditor maupun Kantor Akuntan Publik (KAP) dengan perusahaan klien. Berdasarkan kajian teoritis dan hasil penelitian terdahulu, diketahui bahwa terdapat beberapa faktor yang dapat mempengaruhi keputusan perusahaan klien untuk melakukan pergantian auditor (auditor switching) yaitu opini going concern, financial distress dan kepemilikan institusional. Penelitian ini dilakukan pada seluruh perusahaan manufaktur yang terdaftar di Bursa Efek Indonesia periode 2013-2015. Sampel yang digunakan dalam penelitian ini adalah 140 perusahaan manufaktur yang telah dipilih dengan metode purposive sampling. Pengumpulan data dilakukan dengan menggunakan metode observasi non partisipan. Sementara itu, teknik analisis data yang digunakan dalam penelitian ini adalah analisis regresi logistik. Analisis regresi logistik digunakan dalam penelitian ini karena variabel terikat diukur dengan menggunakan variabel dummy. Berdasarkan hasil analisis dapat disimpulkan bahwa opini going concern dan kepemilikan institusional berpengaruh terhadap auditor switching, sedangkan financial distress tidak berpengaruh terhadap auditor switching.
\end{abstract}

Kata kunci: Auditor switching, opini going concern, financial distress, kepemilikan institusional

\begin{abstract}
Auditor switching is a replacement of the auditor and the Public Accounting Firm (KAP) conducted by the client company. Auditor switching performed by a client company is one of the potential solutions that can be taken to address the possibility of a quality audit degradation problem caused by a long auditor's duration. The problem of decreasing the quality of the audit is caused by the lack of auditor independence and objectivity as well as the Public Accounting Firm (KAP) to the client company due to the long-standing relationship between the auditor and the Public Accounting Firm (KAP) with the client company. Based on the theoretical study and the results of previous research, it is known that there are several factors that can influence the decision of the client company to make auditors switching is going concern opinion, financial distress and institutional ownership.This research was conducted on all manufacturing companies listed in
\end{abstract}


Indonesia Stock Exchange period 2013-2015. The sample used in this research is 140 manufacturing companies that have been selected by purposive sampling method. The data were collected using non participant observation method. Meanwhile, the data analysis technique used in this research is logistic regression analysis. Logistic regression analysis was used in this study because the dependent variables were measured using dummy variables. Based on the analysis results can be concluded that going concern opinion and institutional ownership affect auditor switching, while financial distress does not affect auditor switching.

Keywords: Auditor switching, going concern opinion, financial distress, institutional ownership

\section{PENDAHULUAN}

Auditor switching adalah pergantian auditor maupun Kantor Akuntan Publik (KAP) yang dilakukan oleh perusahaan klien. Pergantian auditor (auditor switching) merupakan suatu hal yang sangat penting untuk dilakukan perusahaan, karena dapat mengatasi munculnya permasalahan penuruanan kualitas audit sebagai akibat dari lamanya hubungan antara auditor dengan perusahaan klien (Cameran et al., 2009). Kewajiban untuk melakukan pergantian auditor (auditor switching) juga diatur oleh Pemerintah Indonesia dengan dikeluarkannya Peraturan Menteri Keuangan Nomor 17/PMK.01/2008 tentang Jasa Akuntan Publik.

Peraturan Menteri Keuangan tersebut menjelaskan bahwa jangka waktu pemberian jasa audit umum oleh Kantor Akuntan Publik terhadap laporan keuangan suatu entitas hanya dapat dilakukan paling lama 6 (enam) tahun buku berturut-turut dan oleh seorang Akuntan Publik hanya dapat dilakukan paling lama 3 (tiga) tahun buku berturut-turut, serta baik Kantor Akuntan Publik maupun seorang Akuntan Publik baru dapat menerima kembali penugasan audit umum untuk perusahaan klien yang sama setelah 1 (satu) tahun buku tidak memberikan jasa audit umum atas laporan keuangan perusahaan klien tersebut. Hal ini turut berperan serta 
ISSN: 2302-8556

E-Jurnal Akuntansi Universitas Udayana

Vol.23.2. Mei (2018): 898-926

menyebabkan perusahaan klien perlu untuk melakukan pergantian auditor (auditor switching), yaitu selain untuk meningkatkan kualitas hasil audit atas laporan keuangan perusahaan klien, juga untuk memenuhi peraturan dan ketentuan yang berlaku (Divianto, 2011)

Namun, pada kenyataannya perusahaan klien melakukan pergantian auditor (auditor switching) tidak hanya karena tuntutan untuk memenuhi regulasi yang berlaku, melainkan juga terdapat beberapa faktor yang mendorong perusahaan klien melakukan pergantian auditor (auditor switching). Beberapa faktor yang dapat memengaruhi keputusan perusahaan klien untuk melakukan pergantian auditor (auditor switching) di antaranya adalah adanya perubahan manajemen, adanya ketidaksepakatan antara perusahaan klien dan auditor, adanya ketidakpuasan atas audit fee (Woo dan Koh, 2001; Tate, 2006; Ismail et al., 2008; Chadegani et al. 2011), munculnya opini audit going concern (Hudaib dan Cook, 2005; Carcello dan Neal, 2003; Calderon and Ofobike, 2008; Svanberg dan Ohman, 2015) dan terjadinya financial distress (Naseer et al., 2006; Chadegani et al. 2011).

Salah satu alasan munculnya opini audit going concern adalah timbulnya suatu dasar pemikiran bahwa perlu untuk dilakukan suatu evaluasi mengenai bagaimana kemampuan perusahaan dalam mempertahankan kelangsungan hidupnya (IAI, 2001:SA Seksi 341). Suatu laporan hasil audit yang telah modifikasi tentang going concern dapat mengindikasikan bahwa dalam penilaian auditor terhadap perusahaan klien, terdapat risiko yang menyebabkan perusahaan klien tidak dapat bertahan dalam bisnis. Oleh karena itu, penerbitan opini audit going concern dapat 
menimbulkan dampak negatif bagi perusahaan klien yang menerimanya, dikarenakan hal tersebut menurunkan tingkat kepercayaan pemegang saham maupun investor terhadap perusahaan klien tersebut, sehingga peran auditor menjadi sangat penting untuk mencegah diterbitkannya laporan keuangan yang menyesatkan. Meskipun auditor tidak bertanggung jawab terhadap kelangsungan hidup perusahaan klien, namun dalam proses audit, kelangsungan hidup perusahaan klien perlu untuk dipertimbangkan oleh auditor dalam memberikan opini (Kartika, 2012).

Hasil penelitian oleh Asti dan Putra (2013) menunjukkan bahwa opini audit going concern tidak berpengaruh terhadap penunjukkan auditor baru oleh perusahaan klien. Hasil penelitian tersebut didukung oleh hasil penelitian Damayanti dan Sudarma (2008), Wijayanti (2010), Wijayani dan Januarti (2011) yang menunjukkan bahwa opini audit going concern tidak berpengaruh pada keputusan perusahaan klien untuk melakukan pergantian auditor. Namun, hasil berbeda di peroleh penelitian Hudaib and Cooke (2006), Calderon and Ofobike (2008), Sudewa (2012) yang menyatakan bahwa opini audit berpengaruh pada keputusan untuk melakukan pergantian auditor. Kondisi seperti ini muncul saat perusahaan klien tidak setuju dengan opini audit going concern yang diberikan auditor, sehingga dapat memicu salah satu pihak memisahkan diri (Calderon and Ofobike, 2008). Hal ini dikarenakan, pada umumnya perusahaan klien menginginkan laporan keuangannya mendapat opini Wajar Tanpa Pengecualian dari auditor maupun Kantor Akuntan Publik (KAP). Hal ini sejalan dengan pernyataan Lennox (2000) dalam Chen et al. (2005) di mana perusahaan yang memperoleh opini audit going concern memiliki kemungkinan yang 
ISSN: 2302-8556

E-Jurnal Akuntansi Universitas Udayana

Vol.23.2. Mei (2018): 898-926

lebih besar untuk melakukan pergantian auditor (auditor switching) dibandingkan dengan perusahaan yang tidak memperoleh opini audit going concern.

Selain opini audit going concern, terjadinya financial distress dalam perusahaan klien diindikasikan dapat menyebabkan kemungkinan terjadinya pergantian auditor (auditor switching). Kesulitan keuangan (financial distress) adalah suatu kondisi dimana arus kas opersasi perusahaan klien tidak mencukupi untuk memenuhi kewajiban lancarnya (Ross et al., 2002). Kondisi ini dapat menyebabkan perusahaan klien akan mengalami arus kas negatif, rasio keuangan yang buruk, gagal memenuhi perjanjian hutang yang ada dan pada akhirnya akan mengarahkan perusahaan klien pada kebangkrutan, sehingga going concern perusahaan klien sangat diragukan. Oleh karena itu, dalam kondisi kesulitan keuangan (financial distress) kemungkinan perusahaan untuk melakukan pergantian auditor (auditor switching) menjadi besar. Hal ini dilakukan perusahaan klien untuk menjaga stabilitas finansialnya.

Hasil penelitian Nasser et al. (2006), Sinarwati (2011) menyatakan bahwa kondisi financial distress memiliki pengaruh pada keputusan perusahaan klien untuk melakukan pergantian auditor (auditor switching), di mana tujuannya adalah untuk menghindari munculnya opini audit going concern dan menjaga stabilitas finansial perusahaan klien. Sedangkan, hasil penelitian berbeda diperoleh Damayanti dan Sudarma (2008), Wijayanti (2010), dan Sudewa (2012) yang menyatakan bahwa financial distress tidak berpengaruh pada keputusan perusahaan klien untuk melakukan pergantian auditor (auditor switching). 
Terakhir, keputusan perusahaan klien melakukan pergantian auditor (auditor switching) disebabkan pula oleh kepemilikan institusional. Kepemilikan institusional merupakan proporsi kepemilikan saham di akhir tahun yang dimiliki oleh lembaga, seperti asuransi, bank atau institusi lain (Tarjo, 2008). Kepemilikan institusional berperan penting dalam pengambilan keputusan mengenai apakah perlu bagi perusahaan klien untuk melakukan pergantian auditor (auditor switching) di periode mendatang. Adanya kepemilikan institusional juga dapat mendorong optimalisasi dalam pengawasan. Perusahaan dengan kepemilikan institusional yang besar mengindikasikan kekuasaannya dalam pengambilan keputusan (Faizal, 2004). Semakin besar kepemilikan institusional dapat menyebabkan semakin efisien pula pemanfaatan aktiva perusahaan klien, serta diharapkan pula dapat bertindak sebagai pengambil keputusan tertinggi.

Jumlah pemegang saham mayoritas (majority shareholders) memiliki peranan penting dalam mengambil keputusan mengenai apakah perlu untuk melakukan pergantian auditor (auditor switching) dalam perusahaan. Adanya konsentrasi dalam kepemilikan saham, akan menyebabkan semakin mudah bagi para pemegang saham besar seperti kepemilikan oleh institusional dalam pengambilan keputusan terkait dengan perlu atau tidaknya pergantian auditor (auditor switching). Tingginya kepemilikan oleh institusi juga dapat meningkatkan pengawasan terhadap kinerja dari auditor, sehingga dapat meminimalkan tingkat kesalahan yang dilakukan oleh pihak auditor yang pada akhirnya menjadi penyebab dari dilakukannya pergantian auditor (auditor switching). Selain itu, pemilik institusional juga tentu akan berusaha untuk 
ISSN: 2302-8556

E-Jurnal Akuntansi Universitas Udayana

Vol.23.2. Mei (2018): 898-926

dapat meningkatkan nilai perusahaan miliknya. Hal ini konsisten dengan hasil penelitian Lins (2002) yang menyatakan bahwa konsentrasi kepemilikan pada pihak luar perusahaan berpengaruh positif terhadap keputusan perusahaan klien untuk melakukan pergantian auditor (auditor switching).

Opini audit merupakan bagian dan informasi utama dari laporan audit yang dibuat oleh auditor maupun Kantor Akuntan Publik. Opini yang diberikan auditor merupakan pernyataan mengenai tingkat kewajaran, dalam semua hal yang material, posisi keuangan dan hasil usaha serta arus kas entitas tertentu apakah telah sesuai dengan prinsip akuntansi berterima umum (PABU). Kawijaya dan Juniarti (2002) menyatakan bahwa opini qualified cenderung kurang disukai oleh perusahaan klien karena akan menimbulkan kesan negatif bagi para investor. Klien akan cenderung berharap memperoleh opini wajar tanpa pengecualian (unqualified opinion) dari Kantor Akuntan Publik atas laporan keuangannya, karena opini wajar tanpa pengecualian menyatakan bahwa data yang disajikan sudah bebas dari kesalahan material dan semua informasi sudah diungkapkan, sehingga dapat menimbulkan kesan positif bagi para investor.

Opini audit yang dimaksud dalam penelitian ini adalah opini yang berisi paragraf penjelas atau menerangkan tentang kelangsungan hidup perusahaan. Hasil penelitian Diyanti (2010) mengungkapkan bahwa kurangnya independensi auditor lama terhadap perusahaan klien dapat menyebabkan perusahaan klien mengambil keputusan untuk melakukan pergantian auditor (auditor switching) sehingga memperoleh opini audit yang menjelaskan tentang kelangsungan hidup perusahaan. 
Auditor switching merupakan perpindahan akuntan publik atau Kantor Akuntan Publik (KAP) yang dilakukan oleh perusahaa klien. Hal ini merupakan salah satu cara yang dilakukan oleh klien untuk menjaga independensi auditor yang mengaudit laporan keuangannya (Mustofa, 2010). Apabila seorang auditor bersikap independen, maka auditor tersebut dapat menjalankan tugasnya dengan baik, serta dapat memberikan opini yang sesuai dengan kondisi perusahaan klien. Berdasarkan uraian tersebut, maka dapat dirumuskan hipotesis sebagai berikut.

$\mathrm{H}_{1}$ : Opini audit going concern berpengaruh positif pada auditor switching

Kesulitan keuangan (financial distress) merupakan suatu kondisi di mana arus kas opersasi perusahaan tidak cukup untuk memenuhi kewajiban lancarnya (Ross et al., 2002). Ramadhany (2004) menyatakan bahwa kondisi keuangan perusahaan dapat menggambarkan apakah sesungguhnya kondisi suatu perusahaan tersebut sehat atau tidak. Kesulitan keuangan (financial distress) yang dialami oleh suatu perusahaan klien dapat diidentifikasi melalui laporan keuangan yang disampaikan, di mana apabila perusahaan memiliki jumlah kewajiban yang lebih besar daripada jumlah kekayaan, maka dapat dikatakan bahwa perusahaan tersebut sedang mengalami kesulitan keuangan (financial distress), dan sebaliknya apabila perusahaan memiliki jumlah kewajiban yang lebih kecil daripada jumlah kekayaan, maka dapat dikatakan bahwa perusahaan tersebut sedang tidak mengalami kesulitan keuangan (financial distress) (Astrini, 2013).

Perusahaan klien yang sedang mengalami kesulitan keuangan (financial distress) dapat memengaruhi keputusan perusahaan klien tersebut untuk melakukan 
ISSN: 2302-8556

E-Jurnal Akuntansi Universitas Udayana

Vol.23.2. Mei (2018): 898-926

pergantian auditor (auditor switching). Hasil penelitian oleh Nasser et al. (2006) menemukan bahwa perusahaan klien yang berada diambang kebangkrutan akibat sedang mengalami kesulitan keuangan (financial distress) cenderung akan lebih sering melakukan pergantian Kantor Akuntan Publik dibandingkan perusahaan yang tidak mengalami kesulitan keuangan (financial distress). Perusahaan klien yang sedang mengalami kesulitan keuangan (financial distress) tentu akan memiliki posisi keuangan yang tidak sehat, sehingga akan memilih untuk melibatkan auditor dengan independensi yang tinggi, sehingga dapat meningkatkan kepercayaan pemegang saham dan kreditur, serta membantu perusahaan untuk mengurangi risiko terkena permasalahan hukum (Nasser et al. 2006). Berdasarkan uraian tersebut dapat ditarik hipotesis sebagai berikut.

$\mathrm{H}_{2}$ : financial distress berpengaruh positif pada auditor switching

Kepemilikan institusional diikuti oleh perubahan kebijakan dalam bidang akuntansi, keuangan, dan pemilihan Kantor Akuntan Publik (Damayanti dan Sudarma, 2008). Kebutuhan para pemegang saham atas jasa audit oleh auditor yang berkualitas pun semakin besar, agar dapat memenuhi tuntutan pertumbuhan perusahaan yang cepat (Joher et al., 2000). Keinginan pemegang saham agar perusahaannya dapat terus berkembang, menyebabkan para pemegang saham cenderung untuk memilih menggunakan jasa audit dari auditor yang berkualitas dan yang dapat memberikan opini audit dengan paragraf penjelas mengenai kelangsungan hidup perusahaan (going concern). 
Pada hubungan antara auditor dengan perusahaan klien, terdapat kemungkinan bahwa kebijakan yang dibuat oleh pemegang saham tidak sejalan dengan auditor. Hal ini dikarenakan auditor dalam menjalankan tugasnya hanya akan melihat apakah kebijakan yang dilaksanakan perusahaan telah sesuai dengan semua peraturan dan ketentuan yang berlaku. Apabila terjadi ketidaksesuain dengan peraturan dan ketentuan yang berlaku, maka perlu bagi auditor untuk mengomunikasikannya dengan perusahaan klien, termasuk memberikan saran. Dalam hal ini, pergantian auditor (auditor switching) dapat terjadi apabila perusahaan klien tidak puas dengan jasa yang diberikan oleh auditor atau selisih paham antara perusahaan klien dengan auditor semakin membesar.

Selain itu, pergantian auditor (auditor switching) juga dapat disebabkan oleh keinginan perusahaan klien untuk meningkatkan kualitas hasil audit atas laporan keuangannya. Nagy (2006) dalam Sinarwati (2010) menyatakan bahwa ketidaksesuaian paham antara auditor dengan pemegang saham seringkali berakhir dengan dilakukannya pergantian auditor (auditor switching). Penyebab lainnya adalah keinginan para pemegang saham agar perusahaannya dapat berkembang, sehingga cenderung akan memilih menggunakan jasa audit oleh auditor yang berkualitas dan dapat memberikan opini audit dengan paragraf penjelas mengenai kelangsungan hidup perusahaan. Berdasarkan uraian tersebut dapat ditarik hipotesis sebagai berikut. $\mathrm{H}_{3}$ : kepemilikan institusional berpengaruh positif pada auditor switching 
ISSN: 2302-8556

E-Jurnal Akuntansi Universitas Udayana

Vol.23.2. Mei (2018): 898-926

\section{METODE PENELITIAN}

Penelitian ini menggunakan pendekatan kualitatif yang dikuantitatifkan yang berbentuk asosiatif, di mana akan diteliti pengaruh yang diberikan oleh opini audit going concern, financial distress dan kepemilikan institusional terhadap audit switching. Berdasarkan permasalahan penelitian, kajian teoritis dan hasil penelitianpenelitian terdahulu, maka desain penelitian ini dapat digambarkan sebagai berikut.

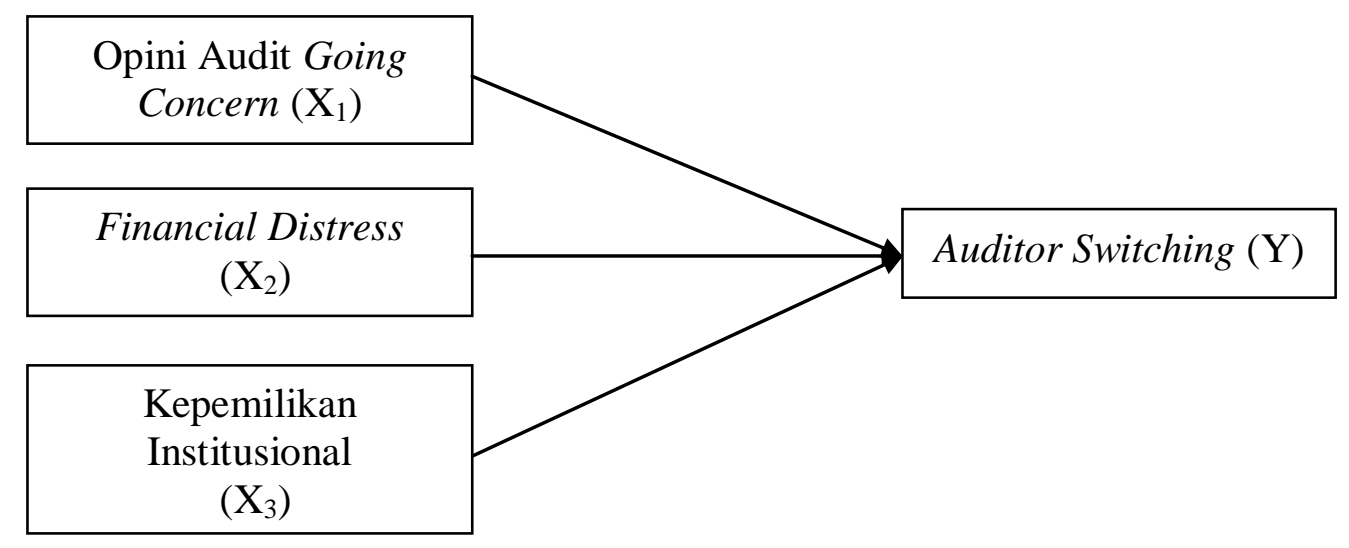

Gambar 1. Desain Penelitian

Sumber: Data diolah, 2017

Penelitian ini dilakukan pada perusahaan-perusahaan manufaktur yang terdaftar di Bursa Efek Indonesia tahun 2013-2015 dengan mengakses website www.idx.co.id. Bursa Efek Indonesia dipilih karena memiliki catatan historis yang lengkap mengenai perusahaan-perusahaan yang telah go public. Selain itu, dikarenakan perusahaan yang terdaftar di BEI diwajibkan untuk melakukan audit atas laporan keungan, sehingga informasi yang disajikan perusahaan menjadi relevan dan reliabel bagi stakeholders. Ruang lingkup penelitian ini terbatas pada pembahasan 
mengenai pengaruh opini audit going concern, financial distress, dan kepemilikan institusional terhadap auditor switching pada perusahaan manufaktur yang terdaftar di Bursa Efek Indonesia periode 2013-2015. Sedangkan, objek penelitian ini adalah perusahaan manufaktur yang mengalami auditor switching dan yang terdaftar di Bursa Efek Indonesia periode 2013-2015.

Variabel terikat dalam penelitian ini adalah auditor switching, yang diukur dengan menggunakan variabel dummy di mana skor dummy 0 diberikan pada perusahaan manufaktur yang tidak menerima opini audit going concern dan skor dummy 1 diberikan pada perusahaan manufaktur yang menerima opini audit going concern. Variabel bebas dalam penelitian ini adalah opini audit going concern, financial distress dan kepemilikan institusional. Opini audit going concern diukur dengan menggunakan variabel dummy di mana skor dummy 0 diberikan pada perusahaan manufaktur yang tidak menerima opini audit going concern dan skor dummy 1 diberikan pada perusahaan manufaktur yang menerima opini audit going concern; financial distress diukur dengan menggunakan Altman Score, di mana dalam mendeteksi kebangkrutan suatu perusahaan, akan digunakan Z-score yang ditentukan dari lima rasio keuangan yang masing-masing dikalikan dengan bobot tertentu untuk menunjukkan tingkat kemungkinan kebangkrutan suatu perusahaan; dan kepemilikan institusional yang diukur dengan melihat proporsi jumlah lembar saham yang dimiliki dibandingkan dengan jumlah lembar saham yang beredar. 
Jenis data dalam penelitian ini adalah data kualitatif dan kuantitatif, di mana data kualitatif berupa daftar perusahaan manufaktur yang tercatat di Bursa Efek Indonesia, laporan auditor independen dan catatan atas laporan keuangan. Data kuantitatif berupa laporan keuangan yang telah diaudit perusahaan manufaktur yang terdaftar di Bursa Efek Indonesia periode 2013-2015. Sementara itu, sumber data yang digunakan dalam penelitian ini adalah data sekunder yang berupa laporan keuangan yang telah diaudit perusahaan manufaktur yang terdaftar di Bursa Efek Indonesia periode 2013-2015

Populasi dalam penelitian ini adalah seluruh perusahaan manufaktur yang terdaftar di Bursa Efek Indonesia selama periode 2013-2015, di mana penentuan sampel penelitian dilakukan dengan menggunakan metode purposive sampling agar memperoleh sampel yang representatif, sesuai dengan kriteria yang telah ditentukan, yaitu perusahaan manufaktur yang terdaftar di Bursa Efek Indonesia periode 20132015 dan perusahaan manufaktur yang melakukan publikasi terhadap laporan keuangannya yang telah diaudit secara lengkap pada tahun 2015. Berdasarkan hasil pengamatan, maka hasil penentuan sampel penelitian ini dapat dilihat pada Tabel 1 sebagai berikut.

Metode pengumpulan data yang digunakan dalam penelitian ini adalah metode observasi non partisipan, dengan mengamati dan mencatat serta mempelajari uraian-uraian dari buku, jurnal, skripsi dan laporan keuangan tahunan perusahaan manufaktur yang terdaftar di Bursa Efek Indonesia dari tahun 2013-2015 yang diakses melalui website www.idx.co.id. 
Tabel 1.

Hasil penentuan Sampel

\begin{tabular}{clc}
\hline No & \multicolumn{1}{c}{ Kriteria Penentuan Sampel } & Sampel \\
\hline 1 & $\begin{array}{l}\text { Perusahaan manufaktur yang terdaftar di BEI periode 2013- } \\
2015\end{array}$ & 401 \\
2 & $\begin{array}{l}\text { Perusahaan manufaktur yang tidak melakukan publikasi } \\
\text { terhadap laporan keuangannya yang telah diaudit pada tahun }\end{array}$ & $(261)$ \\
& 2015 & 140 \\
\hline & Jumlah sampel terseleksi & 420 \\
& Jumlah sampel selama 4 tahun pengamatan
\end{tabular}

Sumber: Data diolah, 2017

Teknik anlisis yang digunakan adalah analisis regresi logistik, dikarenakan variabel terikatnya bersifat kategorikal (nominal), sedangkan variabel bebasnya menggunakan variabel metrik dan non-metrik (Ghozali, 2016:321). Analisis regresi logistik tidak memerlukan asumsi normalitas dan juga mengabaikan masalah heteroskedastisitas. Tahap-tahap untuk melakukan analisis regresi logistik adalah Pertama, menilai kelayakan model regresi dengan menggunakan Hosmer and Lemeshow's Goodness of Fit Test, di mana jika nilai statisik lebih besar daripada 0,05 maka model dapat diterima. Kedua, menilai keseluruhan model (overall model fit) di mana jika ada penurunan nilai antara -2LL awal dengan nilai -2LL pada langkah berikutnya menunjukkan bahwa model hipotesis fit dengan data. Ketiga, mencari nilai koefisien determinasi dengan menggunakan Nagelkerke $R$ Square di mana jika nilainya mendekati 1 berarti variabel bebas telah memberikan hampir semua informasi yang dibutuhkan untuk memprediksi variasi variabel terikat. Keempat, melakukan pengujian multikolinearitas menggunakan matriks korelasi di mana jika nilainya lebih kecil dari 0,90 berarti tidak terdapat gejala multikolinearitas. Kelima, 
membuat matriks klasifikasi untuk memprediksi probabilitas perusahaan tepat waktu atau tidak dalam menyampaikan laporan keuangan. Keenam, model regresi yang terbentuk adalah sebagai berikut.

$$
\operatorname{Ln} \frac{S W I T C H}{1-S W I T C H}=\alpha+\beta_{1} O G C+\beta_{2} F D+\beta_{2} K I+\varepsilon
$$

Keterangan:

$\begin{array}{ll}\text { SWITCH } & : \text { Auditor switching } \\ \alpha & : \text { Konstanta } \\ \beta & : \text { Koefisien regresi variabel independen } \\ \text { OGC } & : \text { Opini auditor going concern } \\ \text { FD } & : \text { Financial distress } \\ \text { KI } & : \text { Kepemilikan institusional } \\ \mathrm{e} & : \text { Error term }\end{array}$

\section{HASIL DAN PEMBAHASAN}

Pengujian statistik deskriptif dilakukan untuk mengetahui gambaran umum tentang karakteristik sampel penelitian, seperti nilai tertinggi, nilai terendah, nilai rata-rata dan standar deviasi dari masing-masing variabel dalam penelitian. Hasil analisis statistik deskriptif dapat dilihat pada Tabel 2 sebagai berikut.

\section{Tabel 2.}

Hasil Statistik Deskriptif

\begin{tabular}{ccccccc}
\hline No & Variabel & N & Min & Max & Mean & Std. Dev \\
\hline 1 & OGC & 420 & 0,00 & 1,00 & 0,291 & 0,455 \\
2 & FD & 420 & 0,06 & 9,46 & 3,313 & 1,675 \\
3 & KI & 420 & 20,93 & 96,31 & 54,308 & 15,814 \\
4 & SWITCH & 420 & 0,00 & 1,00 & 0,314 & 0,465 \\
\hline
\end{tabular}

Sumber: Data diolah, 2017

Berdasarkan Tabel 2 pada opini audit going concern $\left(\mathrm{X}_{1}\right)$ diperoleh nilai terendah (minimum) dan nilai tertinggi (maximum) masing-masing sebesar 0,00 dan 
1,00. Nilai rata-rata opini audit going concern adalah sebesar 0,291 menunjukkan bahwa lebih banyak perusahaan manufaktur yang tidak memperoleh opini audit going concern dari auditor maupun Kantor Akuntan Publik (KAP). Sedangkan, nilai standar deviasi opini audit going concern adalah sebesar 0,455 menunjukkan bahwa nilai standar deviasi lebih besar daripada nilai rata-rata, sehingga tingkat sebaran data pada variabel opini audit going concern relatif tinggi.

Pada variabel financial distress $\left(\mathrm{X}_{2}\right)$ diperoleh nilai terendah (minimum) dan nilai tertinggi (maximum) masing-masing sebesar 0,06 dan 9,46. Nilai rata-rata financial distress adalah sebesar 3,313 menunjukkan bahwa rata-rata sebagian besar perusahaan manufaktur dalam kondisi keuangan yang baik atau tidak mengalami kesulitan keuangan (financial distress). Sedangkan, nilai standar deviasi financial distress adalah sebesar 1,675 menunjukkan bahwa nilai standar deviasi lebih kecil daripada nilai rata-rata, sehingga tingkat sebaran data pada variabel financial distress relatif rendah.

Pada variabel kepemilikan institusional $\left(\mathrm{X}_{3}\right)$ diperoleh nilai terendah (minimum) dan nilai tertinggi (maximum) masing-masing sebesar 20,93 dan 96,31. Nilai rata-rata kepemilikan institusional adalah sebesar 54,308 menunjukkan bahwa rata-rata kepemilikan institusional bertindak sebagai pemegang saham mayoritas di perusahaan manufaktur. Sedangkan, nilai standar deviasi kepemilikan institusional adalah sebesar 15,814 menunjukkan bahwa nilai standar deviasi lebih kecil daripada nilai rata-rata, sehingga tingkat sebaran data pada variabel kepemilikan institusional relatif rendah. 
ISSN: 2302-8556

E-Jurnal Akuntansi Universitas Udayana

Vol.23.2. Mei (2018): 898-926

Pada variabel auditor switching (Y) diperoleh nilai terendah (minimum) dan nilai tertinggi (maximum) masing-masing sebesar 0,00 dan 1,00. Nilai rata-rata auditor switching adalah sebesar 0,314 menunjukkan sebagian besar perusahaan manufaktur tidak melakukan kebijakan pergantian auditor (auditor switching). Sedangkan, nilai standar deviasi auditor switching adalah sebesar 0,465 menunjukkan bahwa nilai standar deviasi lebih besar daripada nilai rata-rata, sehingga tingkat sebaran data pada variabel financial distress relatif tinggi.

Uji kelayakan model regresi dalam penelitian ini dilakukan dengan menggunakan Hosmer and Lemeshow's Goodness of Fit Test, di mana akan diuji hipotesis nol apakah data cocok atau sesuai dengan model, sehingga model regesi dapat dikatakan fit. Hasil uji kelayakan model regresi dapat dilihat pada Tabel 3 sebagai berikut.

Tabel 3.

Hasil Uji Hosmer and Lemeshow

\begin{tabular}{cccc}
\hline Step & Chi-square & Df & Sig \\
\hline 1 & 3,998 & 8 & 0,857 \\
\hline
\end{tabular}

Sumber: Data diolah, 2017

Berdasarkan Tabel 3 dapat dilihat bahwa nilai Chi-square sebesar 3,998 dengan nilai sig. sebesar 0,857 . Hal ini menunjukkan bahwa nilai sig. sebesar 0,857 lebih besar daripada 0,05, sehingga model regresi dapat dikatakan fit karena data observasi cocok atau sesuai dengan model regresi.

Menilai keseluruhan model (overall model fit) dilakukan berdasarkan pada fungsi likelihood dengan membandingkan nilai antara -2LL pada awal (Block Number $=0)$ dengan nilai -2LL pada akhir (Block Number $=1$ ), di mana apabila terjadi 
penurunan nilai -2LL menunjukkan bahwa model yang dihipotesiskan telah fit dengan data. Hasil pengujian dapat dilihat pada Tabel 4 sebagai berikut.

Tabel 4.

Hasil Uji Perbandingan Nilai -2LL Awal dengan -2LL Akhir

-2LL (Block Number $=0$ ) pada awal 523,016

-2LL (Block Number $=1$ ) pada akhir $\quad 522,889$

Sumber: Data diolah, 2017

Berdasarkan Tabel 4 menunjukkan bahwa terjadi penurunan nilai -2LL, yaitu sebesar 523,016 pada -2LL awal (Block Number $=0$ ) menjadi sebesar 522,889 pada -2LL akhir (Block Number $=1$ ), sehingga dapat dikatakan bahwa model regresi yang dihipotesiskan telah fit dengan data.

Uji koefisien determinasi dilakukan dengan menggunakan Nagelkerke's $R$ Square yang bertujuan untuk mengukur seberapa besar variabel bebas yang digunakan dalam penelitian ini, yaitu opini audit going concern, financial distress dan kepemilikan institusional mampu memengaruhi variabel terikat yang digunakan dalam penelitian ini, yaitu auditor switching. Hasil uji koefisien determinasi dapat dilihat pada Tabel 5 sebagai berikut.

Tabel 5.

Hasil Uji Koefisien Determinasi (Nagelkerke's r Square)

\begin{tabular}{cccc}
\hline Step & $\mathbf{- 2}$ Log Likelihood & Cox \& Snell R Square & Nagelkerke's R Square \\
\hline 1 & 514,098 & 0,721 & 0,429 \\
\hline Sumber: Data diolah, 2017 & &
\end{tabular}

Berdasarkan Tabel 5 menunjukkan nilai Nagelkerke's $R$ Square adalah sebesar 0,429. Hal ini menunjukkan bahwa variabel bebas dalam penelitian ini mampu menjelaskan $42,9 \%$ variabilitas variabel terikat, sedangkan sisanya $57,1 \%$ 
variabilitas variabel terikat dapat dijelaskan oleh variabel lain yang tidak terdapat di dalam model regresi ini.

Model regresi yang baik adalah model regesi yang tidak memiliki gejala terjadinya korelasi yang kuat diantara variabel-variabel bebasnya. Oleh karena itu, pada analisis regresi logistik dilakukan uji multikolinearitas dengan menggunakan matriks korelasi, untuk mengetahui apakah terjadi atau tidak gejala korelasi yang kuat diantara variabel-variabel bebas. Apabila nilai matrik korelasi lebih kecil dari 0,9 maka tidak terdapat gejala multikolinearitas. Sebaliknya, apabila nilai matriks korelasi lebih besar dari 0,9 maka terdapat gejala multikolinearitas. Hasil uji multikolinearitas dapat dilihat pada Tabel 6 sebagai berikut.

\section{Tabel 6.}

\section{Matriks Korelasi}

\begin{tabular}{cccccc}
\hline & & Constant & X1 & X2 & X3 \\
\hline Step 1 & Constant & 1,000 & $-0,477$ & $-0,581$ & $-0,739$ \\
& X1 & $-0,477$ & 1,000 & 0,586 & $-0,016$ \\
& X2 & $-0,581$ & 0,586 & 1,000 & $-0,046$ \\
& X3 & $-0,739$ & $-0,016$ & $-0,046$ & 1,000 \\
\hline
\end{tabular}

Sumber: Data diolah, 2017

Berdasarkan Tabel 6 menunjukkan bahwa tidak ada nilai koefisien korelasi antara variabel bebas yang nilainya lebih besar dari 0,9 sehingga dapat disimpulkan bahwa dalam model regesi ini tidak terdapat gejala multikolinearitas atau tidak terdapat korelasi yang kuat diantara variabel-variabel bebas.

Matriks klasifikasi menunjukkan kekuatan prediksi dari model regresi untuk memprediksi tingkat probabilitas terjadinya pergantian auditor (auditor switching) yang dilakukan oleh perusahaan manufaktur yang terdaftar di Bursa Efek Indonesia 
selama periode 2013-2015. Matriks klasifikasi dapat dilihat pada Tabel 7 sebagai berikut.

Tabel 7.

Matriks Klasifikasi

\begin{tabular}{cccccc}
\hline \multirow{2}{*}{ Observed } & & \multicolumn{3}{c}{ Predicted } \\
\cline { 3 - 6 } & & & $\mathbf{0 , 0 0 0 0}$ & $\mathbf{1 , 0 0 0 0}$ & $\begin{array}{c}\text { Percentage } \\
\text { Correct }\end{array}$ \\
\hline \multirow{2}{*}{ Step 1 } & SWITCH & 0,0000 & 0 & 1 & 100 \\
& & 1,0000 & 288 & 0 & 0 \\
& & Overall Percentage & 132 & & 68,6 \\
\hline
\end{tabular}

Sumber: Data diolah, 2017

Berdasarkan Tabel 7 menunjukkan kekuatan prediksi model regresi untuk memprediksi probabilitas perusahaan manufaktur menerima opini audit going concern dan tidak menerima opini audit going concern adalah masing-masing sebesar 68,6 persen. Selain itu, dapat diketahui juga bahwa di dalam model regresi ini, terdapat sebanyak 288 perusahaan manufaktur yang tidak melakukan pergantian auditor (auditor switching) dan 132 perusahaan manufaktur yang melakukan pergantian auditor (auditor switching).

Analisis yang digunakan dalam penelitian ini adalah analisis regresi logistik biner, yaitu dengan melihat pengaruh opini audit going concern, financial distress dan kepemilikan institusional terhadap auditor switching. Pengujian hipotesis dilakukan dengan membandingkan nilai signifikansi (sig.) dengan tingkat kesalahan $(\alpha)$, di mana apabila sig. > 0,05 maka variabel bebas berpengaruh signifikan terhadap variabel terikat. Hasil analisis regresi logistik pada penelitian ini dapat dilihat pada Tabel 8 sebagai berikut. 
ISSN: 2302-8556

E-Jurnal Akuntansi Universitas Udayana

Vol.23.2. Mei (2018): 898-926

Tabel 8.

Hasil Analisis Regresi Logistik

\begin{tabular}{lcccccc}
\hline & & B & S.E. & Wald & Df & Sig. \\
\hline Step 1 & X1 & 0,620 & 0,278 & 4,980 & 1 &, 026 \\
& X2 & 0,015 & 0,078 & 0,038 & 1 &, 845 \\
& X3 & 0,004 & 0,007 & 0,377 & 1 &, 039 \\
& Constant & $-0,704$ & 0,475 & 2,196 & 1 &, 138 \\
\hline
\end{tabular}

Sumber: Data diolah, 2017

Berdasarkan Tabel 8 maka model regresi yang terbentuk adalah sebagai berikut:

$$
\operatorname{Ln} \frac{S W I T C H}{1-S W I T C H}=-0,704+0,620 G C+0,015 F D+0,004 K I+\varepsilon
$$

Berdasarkan model regresi yang terbentuk pada Tabel 8 dapat diketahui bahwa konstanta memiliki nilai sebesar -0,704. Hal ini menunjukkan bahwa jika variabel opini audit going concern, financial distress dan kepemilikan institusional bernilai konstan maka kemungkinan terjadinya pergantian auditor (auditor switching) menurun sebesar $70,4 \%$.

Variabel opini audit going concern memiliki nilai koefisien regresi sebesar 0,620. Hal ini menunjukkan bahwa apabila perusahaan manufaktur memperoleh opini audit going concern dari auditor maupun Kantor Akuntan Publik maka terdapat kemungkinan besar terjadi pergantian auditor (auditor switching), dengan asumsi bahwa variabel-variabel lainnya bernilai konstan.

Variabel financial distress memiliki nilai koefisien regresi sebesar 0,015. Hal ini menunjukkan bahwa apabila perusahaan manufaktur mengalami kesulitan keuangan (financial distress), maka akan semakin besar kemungkinan perusahaan 
klien untuk melakukan pergantian auditor (auditor switching) dengan asumsi bahwa variabel-variabel lainnya bernilai konstan.

Variabel kepemilikan institusional memiliki nilai koefisien regresi sebesar 0,004. Hal ini menunjukkan bahwa apabila kepemilikan institusional terhadap perusahaan manufaktur relatif tinggi atau kepemilikan institusional memegang saham mayoritas di perusahaan manufaktur, maka kemungkinan terjadinya pergantian auditor (auditor switching) juga akan semakin tinggi, dengan asumsi bahwa variabelvariabel lainnya bernilai konstan.

Opini audit going concern memiliki nilai koefisien regresi sebesar 0,620 dengan tingkat signifikansi sebesar 0,026 yang berarti lebih kecil daripada 0,05. Hal ini menunjukkan bahwa secara parsial opini audit going concern berpengaruh terhadap pergantian auditor (auditor switching) yang dilakukan oleh perusahaan manufaktur yang terdaftar di Bursa Efek Indonesia periode 2013-2015. Dengan demikian, $\mathrm{H}_{1}$ diterima.

Financial distress memiliki nilai koefisien regresi sebesar 0,015 dengan tingkat signifikansi sebesar 0,845 yang berarti lebih besar daripada 0,05 . Hal ini menunjukkan bahwa secara parsial financial distress tidak berpengaruh terhadap pergantian auditor (auditor switching) yang dilakukan oleh perusahaan manufaktur yang terdaftar di Bursa Efek Indonesia periode 2013-2015. Dengan demikian, $\mathrm{H}_{2}$ ditolak.

Kepemilikan institusional memiliki nilai koefisien regresi sebesar 0,004 dengan tingkat signifikansi sebesar 0,039 yang berarti lebih kecil daripada 0,05. Hal 
ISSN: 2302-8556

E-Jurnal Akuntansi Universitas Udayana

Vol.23.2. Mei (2018): 898-926

ini menunjukkan bahwa secara parsial kepemilikan institusional berpengaruh terhadap pergantian auditor (auditor switching) yang dilakukan oleh perusahaan manufaktur yang terdaftar di Bursa Efek Indonesia periode 2013-2015. Dengan demikian, $\mathrm{H}_{3}$ diterima.

Berdasarkan hasil analisis regresi logistik, diketahui bahwa opini audit going concern berpengaruh terhadap keputusan perusahaan manufaktur untuk melakukan pergantian auditor (auditor switching), di mana apabila perusahaan manufaktur memperoleh opini audit going concern dari auditor maupun Kantor Akuntan Publik, maka akan meningkatkan kemungkinan terjadinya pergantian auditor (auditor switching). Hal ini dapat terjadi karena terdapat kekhawatiran pada perusahaan manufaktur ketika memperoleh opini audit going concern, sehingga perusahaan akan berusaha untuk mencari auditor baru yang dianggap dapat diajak bekerjasama untuk menurunkan kemungkinan perusahaan memperoleh opini audit going concern. Dengan adanya pergantian auditor (auditor switching) diharapkan akan dapat memberikan opini audit yang berbeda dan lebih baik sehingga tidak menurunkan reputasi perusahaan. Hasil penelitian ini sejalan dengan penelitian yang dilakukan oleh Kumalawati (2012) dan Diyanti (2010) yang menyatakan bahwa opini audit going concern berpengaruh pada auditor switching.

Berdasarkan hasil analisis regresi logistik, diketahui bahwa financial distress tidak berpengaruh terhadap keputusan perusahaan manufaktur untuk melakukan pergantian auditor (auditor switching). Hasil penelitian ini tidak sejalan dengan penelitian yang dilakukan oleh Sentosa dan Wedari (2007) dan McKeown et al. 
(1991) yang menyatakan bahwa perusahaan klien akan melakukan pergantian auditor (auditor switching) ketika sedang mengalami kesulitan keuangan (financial distress). Namun, hasil penelitian ini didukung oleh penelitian yang dilakukan oleh Astuti (2012) dan Januarti (2008) yang menyatakan bahwa financial distress tidak berpengaruh pada keputusan untuk melakukan pergantian auditor (auditor switching). Hal ini terjadi karena perusahaan klien yang sedang mengalami kesulitan keuangan (financial distress) merasa perlu untuk mendapatkan saran-saran perbaikan dari auditor yang melakukan audit pada perusahaan agar dapat keluar dari kondisi financial distress.

Berdasarkan hasil analisis regresi logistik, diketahui bahwa kepemilikan institusional berpengaruh terhadap keputusan perusahaan manufaktur untuk melakukan pergantian auditor (auditor switching). Perusahaan dengan kepemilikan yang terkonsentrasi seperti kepemilikan institusional akan dilindungi oleh hak kepemilikannya, sehingga memiliki kewenangan untuk menentukan kebijakan perusahaan, salah satunya apakah perlu atau tidak untuk melakukan pergantian auditor (auditor switching). Pada umumnya, kepemilikan institusional sebagai pemegang saham mayoritas cenderung memanfaatkan kewenangan yang dimilikinya untuk kepentingan pribadi ataupun kelompok, sehingga ketika pemegang saham memiliki konflik dengan auditor maupun Kantor Akuntan Publik yang melakukan audit terhadap perusahaan, maka mereka akan melakukan pergantian auditor (auditor switching) (Eisenhardt, 1989). Hasil penelitian ini sejalan dengan penelitian yang dilakukan oleh Anderson et al., 2003 dan Claessens et al., 2002 yang menyatakan 
ISSN: 2302-8556

E-Jurnal Akuntansi Universitas Udayana

Vol.23.2. Mei (2018): 898-926

bahwa kepemilikan institusional dapat berpengaruh terhadap pergantian auditor (auditor switching).

\section{SIMPULAN}

Berdasarkan hasil analisis dan pembahasan yang telah dilakukan, dapat disimpulkan bahwa opini audit going concern berpengaruh positif terhadap keputusan untuk melakukan pergantian auditor (auditor switching) oleh perusahaan manufaktur yang terdaftar di Bursa Efek Indonesia periode 2013-2015. Financial distress tidak berpengaruh terhadap keputusan untuk melakukan pergantian auditor (auditor switching) oleh perusahaan manufaktur yang terdaftar di Bursa Efek Indonesia periode 2013-2015. Kepemilikan institusional berpengaruh positif terhadap keputusan untuk melakukan pergantian auditor (auditor switching) oleh perusahaan manufaktur yang terdaftar di Bursa Efek Indonesia periode 2013-2015.

Berdasarkan hasil penelitian dan simpulan di atas, maka saran yang dapat disampaikan agar dapat menjadi pertimbangan bagi para investor dan kreditur dalam pengambilan keputusan investasi di perusahaan manufaktur yang terdaftar di Bursa Efek Indonesia, khususnya dalam menganalisis informasi audit yang dilakukan oleh auditor maupun Kantor Akuntan Publik. Disarankan pula kepada pihak auditor untuk meningkatkan kualitas audit agar semakin baik lagi. Dalam penelitian ini pula terdapat keterbatasan-keterbatasan yang dapat menjadi bahan pertimbangan bagi peneliti selanjutnya, sehingga disarankan agar peneliti selanjutnya memperpanjang waktu amatan agar lebih terlihat jelas auditor switching yang dilakukan oleh 
perusahaan klien apakah dilakukan untuk memenuhi regulasi atau karena berdasarkan kepentingan lain. Selain itu, disarankan pula untuk mempertimbangkan variabelvariabel lain yang mungkin dapat berpengaruh terhadap keputusan perusahaan untuk melakukan pergantian auditor (auditor switching).

\section{REFERENSI}

Arlen Djunaidi dan Gatot Soepriyanto. 2009. Pengaruh Pergantian Auditor dan Kualitas Audit Terhadap Opini Going Concern Studi Empiris Perusahaan Manufaktur di Bursa Efek Indonesia. Accounting and Finance Journal, Faculty of Bisnis and Communication. BINUS University: Jakarta

Astuti, Irtanti Retno. 2012. Pengaruh Faktor Keuangan dan Non Keuangan Terhadap Penerimaan Opini Audit Going Concern. Jurnal Akuntansi, 1 (2), h: 1-10

Astrini, Novia Retno. 2013. Analisis Faktor-Faktor yang Mempengaruhi Perusahaan Melakukan Auditor Switching Secara Voluntary. Skripsi. Fakultas Ekonomika dan Bisnis Universitas Diponegoro, Semarang

Calderon, Thomas G. and Emeka Ofobike. 2008. Determinants of Client-initiated and Auditor-initiated Auditor Changes. Managerial Auditing Journal, 23 (1), pp: 24-32

Cameran, Mara, Annalisa Prencipe, \& Marco Trombeta. 2009. Does Mondatory Audit Firm Rotation Really Improve Audit Quality. Annual Meeting New York, pp: 1-10

Carcello, J.V., dan T.L. Neal. 2003. Audit Committee Characteristics and Auditor Dismissals following New Going Concern Reports. The Accounting Review, 78 (1), pp: $95-105$

Chadegani, Arezoo Aghaei, Zakiah Muhhammadun Mohamed and Azam Jari. 2011. The Determinant Factors of Audit Switch Among Companies Listed on Tehran stock Exchange. International Research Journal of Finance and Economics

Chen, Ching-Lung, Fu Hsing Chang and Gili Yen. 2005. The Information Contents of Auditor Change In Financial Distress Prediction - Empirical Findings from the TAIEX-listed firms. www.google.com 
Divianto. 2011. Faktor-Faktor Yang Mempengaruhi Perusahaan Dalam Melakukan Auditor Switch. Jurnal Ekonomi dan Informasi Akuntansi, 1(2)

Diyanti, Fitri Tri. (2010). Pengaruh Debt Default, Pergantian Auditor, dan Ukuran Perusahaan terhadap Penerimaan Opini Audit Going Concern. Skripsi Fakultas Ekonomi Universitas Gunadarma, Depok

Eisenhardt, K. M. 1989. Agency Theory: An Assesment and Review. Academy of Management Riview, 14 (1), h: 57-74

Gozali, Imam. 2013. Aplikasi Analisis Multivariate dengan Program IMB SPSS 21. Edisi Ketujuh. Badan Penerbit Universitas Diponegoro: Semarang

Hudaib, Mohammad. dan Cooke, T. E., 2005. The Impact of Managing Director Changes and Financial Distress on Audit Qualification and Auditor Switching. Jurnal of Business Financial and Accounting, 32 (9), pp: 17031739

Ismail, Shahnaz, Aliahmed, Huson Joher, Nassir, Annuar Md., dan Hamid, Mohamad Ali Abdul. 2008. Why Malaysian Second Board Companies Switch Auditor: Evidence of Bursa Malaysia. International Research Journal of Finance and Economics, Vol. 13, h: 123-130

Januarti, Indira dan Ella Fitrianasari. 2008. Analisis Rasio Keuangan dan Rasio Non Keuangan Yang Mempengaruhi Audit Dalam Memberikan Opini Audit Going Concern Pada Auditee. Jurnal Magister Akuntansi, 8 (1), h: 44-45

Jensen, M. C. Dan W H Meckling. 1976. Theory of the Firm: Managerial Behavior, Agency Cost and Ownership Structure. Journal of Financial Economics, Vol. 3, pp: 305-316

Kartika, Andi. 2012. Pengaruh Kondisi Keuangan dan Non Keuangan Terhadap Penerimaan Opini Going Concern pada Perusahaan Manufaktur di BEI. Dinamika Akuntansi, Keuangan dan Perbankan, Vol. 1, h: 25-40

Kumalawati, Lely. 2012. Faktor-Faktor yang Mempengaruhi Opini Going Concern: Studi Empiris pada Perusahaan Manufaktur yang Terdapat di Bursa Efek Indonesia. Jurnal Akuntansi dan Ekonomi Bisnis, Vol. 1

McKeown, J. Mutchler, J dan Hopwood W. 1991. Towards an Explanation of Auditor Failure to modify the Audit Opinion of Bankrupt Companies. A Journal Practice \& Theory. Supplement, pp: 1-13 
Mustofa, Diana. 2010. The Impact of Auditor Rotation on The Audit Quality: A Field Study from Egypt. Working Paper. Faculty of Management Technology The German University, Cairo

Nasser, Abu T.; Wahid, Emelin A.; Nazri, Sharifah N. F. S. M. dan Hudaib, Mohammad. 2006. Auditor-Client Relationship: The Case of Audit Tenure and Auditor Switching in Malaysia. Managemen Auditing Journal, 21 (7), pp: 724-737

Ramadhany, Alexander. 2004. Analisis Faktor-Faktor yang Mempengaruhi Penerimaan Opini Audit Going Concern pada Perusahaan Manufaktur yang Terdaftar di BEJ. Thesis. Semarang: Program Pasca Sarjana Universitas Diponegoro

Ross, Stephen. R. W. Westerfield dan J.Jaffe. 2002. Corporate Finance. MCGrawHill: New York

Santosa, Arga F. Dan Linda K. Wedari. 2007. Analisis Faktor-Faktor yang mempengaruhi Kecenderungan Penerimaan Opini Audit Going Concern, JAAI, 11 (3), h: 141-158

Sinarwati, Ni Kadek. 2010. Mengapa Perusahaan Manufaktur yang Terdapat di BEI Melakukan Pergantian Kantor Akuntan Publik?. Simposium Nasional Akuntansi XIII

Susanto, Y. Kurnia. 2009. Faktor-faktor yang Mempengaruhi Penerimaan Opini Audit Going Concern Pada Perusahaan Publik Sektor Manufaktur. Jurnal Bisnis dan Akuntansi, 11 (3), h: 155-173

Sutedja, Christian. 2010. Faktor-faktor yang Berpengaruh Terhadap Pemberian Opini Audit Going Concern pada Perusahaan Manufaktur. Jurnal Akuntansi Kontemporer, 2 (2), h: 154-161

Svanberg, J. dan P. Ohman. 2014. Lost Revenues Associated with Going Concern Modified Opinions in the Swedish Audit Market. Journal of Applied Accounting Research, 15 (2), pp: 197-214

Tate, S. L. 2006. Auditor Chage ang Auditor Choice in Non-Profit Organization. Departement of Accounting and Finance University of New Hampshire 
ISSN: 2302-8556

E-Jurnal Akuntansi Universitas Udayana

Vol.23.2. Mei (2018): 898-926

Venuti, Elizabeth K. 2007. The Going Concern Assumption Revisited: Assessing a Company's Future Viability. The CPA Journal Online

Woo, E-Sah dan Koh, Hian Chye. 2001. Factor Associated With Auditor Change: A Singapore Study. Accounting and Business Research, 31 (2), pp: 133-144 